\title{
Multipotent (adult) and pluripotent stem cells for heart regeneration: what are the pros and cons?
}

\author{
Song-Yan Liao ${ }^{1}$ and Hung-Fat Tse $\mathrm{T}^{1,2^{*}}$
}

\begin{abstract}
Heart failure after myocardial infarction is the leading cause of mortality and morbidity worldwide. Existing medical and interventional therapies can only reduce the loss of cardiomyocytes during myocardial infarction but are unable to replenish the permanent loss of cardiomyocytes after the insult, which contributes to progressive pathological left ventricular remodeling and progressive heart failure. As a result, cell-based therapies using multipotent (adult) stem cells and pluripotent stem cells (embryonic stem cells or induced pluripotent stem cells) have been explored as potential therapeutic approaches to restore cardiac function in heart failure. Nevertheless, the optimal cell type with the best therapeutic efficacy and safety for heart regeneration is still unknown. In this review, the potential pros and cons of different types of multipotent (adult) stem cells and pluripotent stem cells that have been investigated in preclinical and clinical studies are reviewed, and the future perspective of stem cell-based therapy for heart regeneration is discussed.
\end{abstract}

\section{Introduction}

Heart failure (HF) due to loss of cardiomyocytes caused by myocardial injuries, especially myocardial infarction (MI), is the leading cause of mortality and morbidity worldwide [1]. Current pharmacological and interventional therapies can only reduce the loss of cardiomyocytes during MI but are unable to replenish the permanent loss of cardiomyocytes after the initial insult, which contributes to progressive pathological left ventricular (LV) remodeling. Indeed, a significant proportion of MI survivors develop progressive HF despite successful revascularization of the coronary arteries. While heart transplantation is a curative therapy

\footnotetext{
* Correspondence: hftse@hkucc.hku.hk

${ }^{1}$ Cardiology Division, Department of Medicine, Queen Mary Hospital, The University of Hong Kong, Hong Kong, HKSAR, China

${ }^{2}$ Research Centre of Heart, Brain, Hormone and Healthy Ageing, Li Ka Shing

Faculty of Medicine, The University of Hong Kong, Hong Kong, HKSAR, China
}

for severe HF, this therapy is only feasible in a minority of HF patients due to limited organ supply. As a result, cellbased therapies using multipotent stem cells (adult stem cells) and pluripotent stem cells (embryonic stem cells (ESCs) or induced pluripotent stem cells (iPSCs)) have been explored as potential therapeutic approaches for cardiac regeneration. Nevertheless, the optimal delivery method, efficiency and safety of these different types of stem cells for transplantation are still unknown. The objective of this review is to evaluate the pros and cons of different stem cell-based therapy approaches for heart regeneration in pre-clinical and clinical studies.

\section{Promises of stem cell therapy for heart regeneration} While multipotent cardiac stem cells (CSCs) exist in mammalian heart, they only contribute to very limited numbers of new cardiomyocytes after birth. Dedifferentiation of the existing cardiomyocytes rather than cardiogenesis from endogenous CSCs appears to be the major mechanism of myocardial repair during aging and after injury [2]. Unfortunately, these mechanisms are rather ineffective for myocardial regeneration in mammalian hearts and decline with age. As a result, transplantation of exogenous stem cells into the injured heart to enhance cardiogenesis has been investigated as a therapeutic approach for heart regeneration.

Currently, two major types of stem cells are being investigated: multipotent stem cells (adult stem cells) and pluripotent stem cells (ESCs or iPSCs) have been studied as potential cell sources for heart regeneration. Adult stem cells can be isolated from different tissues, such as skeletal muscle, adipose tissue, peripheral blood or bone marrow (BM), while ESCs and iPSCs are pluripotent stem cells that are isolated from blastocysts of human embryos and derived via reprogramming from somatic cells, respectively (Figure 1). Pre-clinical and clinical studies showed that transplantation of these multipotent or pluripotent stem cells can improve cardiac function in infarcted heart. Nevertheless, the mechanism by which these stem cells improve cardiac function after transplantation remains unclear. While the initial promise is that these transplanted 


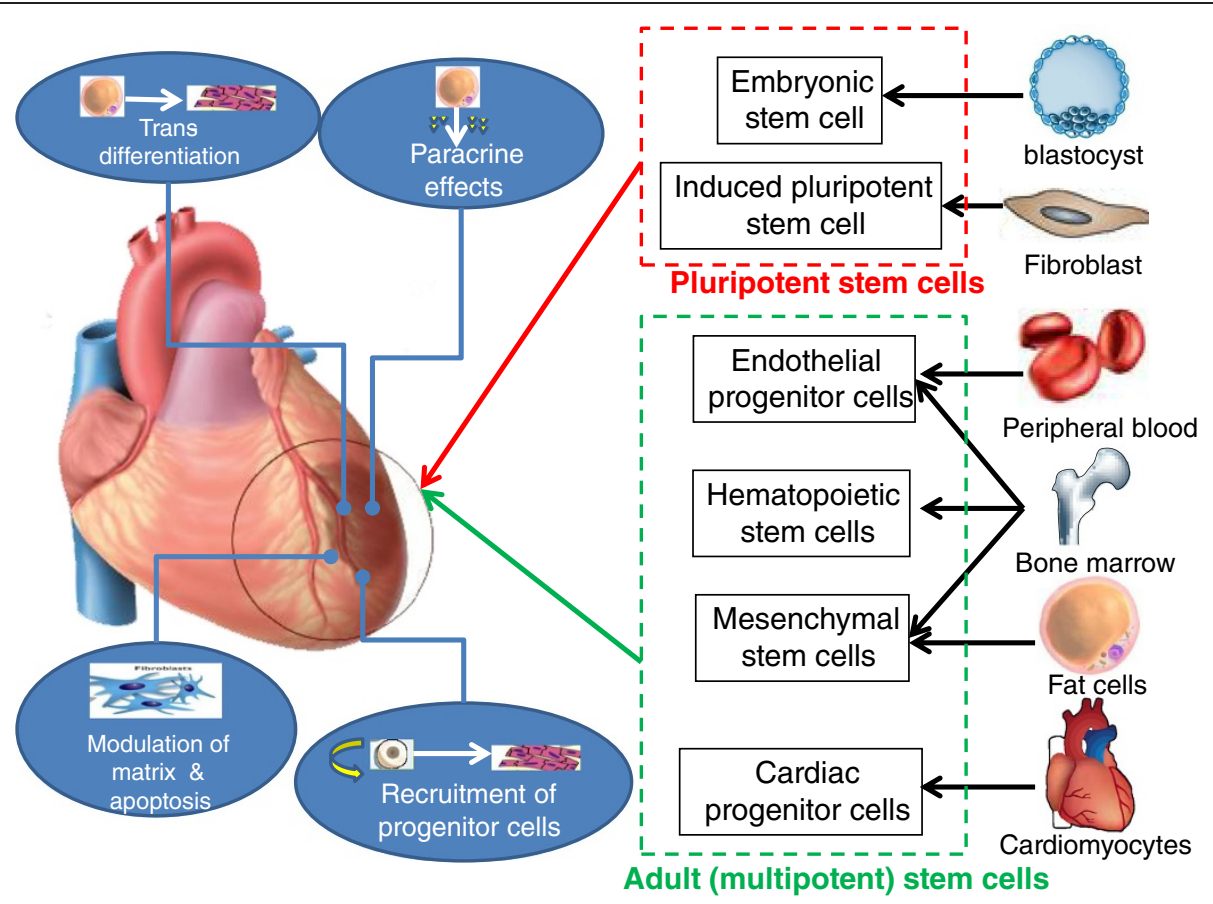

Figure 1 Types of adult (multipotent) and pluripotent stem cells for heart regeneration.

stem cells can directly differentiate into cardiomyocytes, most recent studies have suggested that neither multipotent $[3,4]$ nor pluripotent stem cells $[5,6]$ can survive long term and thus do not directly contribute to substantial heart regeneration. These findings suggest that most of their beneficial effects on heart function after transplantation are attributed to various degrees of other indirect actions, including paracrine actions $[7,8]$, modulation of extracellular matrix and apoptosis [9] and mobilization of endogenous stem cells [10] (Figure 1). Unfortunately, the paracrine factors secreted or released as well as the relative contributions of other indirect repair mechanisms that are attributed to different types of stem cells for the improvement of cardiac function have yet to be determined. On the other hand, direct cardiac regeneration using pluripotent stem cells might still be achievable if some of the major hurdles related to their preparation, engraftment and survival can be addressed in the future.

\section{Types of stem cells}

\section{Multipotent (adult) stem cells}

Different types of adult stem cells that are proven to be multipotent, including skeletal myoblasts, hematopoietic stem cells (HSCs), endothelial progenitor cells (EPCs), mesenchymal stem cells (MSCs), and CSCs, have been investigated for heart regeneration (Figure 1). These adult stem cells can be isolated from patients for autologous transplantation without risk of immunological rejection, and thus are more feasible and readily available for clinical testing. Indeed, these stem cells are currently being investigated for treatment of acute MI, chronic myocardial ischemia and HF (Figure 2).

\section{Skeletal myoblasts}

Skeletal myoblasts are skeletal muscle precursor cells that can be isolated from skeletal muscle biopsies and expanded ex vivo to quantities sufficient for autologous transplantation [11]. In an animal model of MI, skeletal myoblasts engrafted into the infarcted myocardium and could be differentiated into myotubules after transplantation to improve cardiac function [12]. Unfortunately, subsequent clinical trials showed that skeletal myoblast transplantation did not improve cardiac function after HF and may increase the risk of ventricular tachyarrhythmias. The proarrhythmia that occurs after skeletal myoblast transplantation may be attributed to the loss of connexin- 43 expression after in vitro differentiation and results in the failure of electrical integration with the host myocardium [13]. While these studies suggest that skeletal myoblasts might not be the optimal cell type for cardiac regeneration, the insights obtained from these results have highlighted the important issue of potential proarrhythmias after stem cell therapy.

\section{Bone marrow-derived cells}

Adult BM is a rich source of stem cells - HSCs, EPCs and MSCs constitute up to approximately $2 \%$ of the total BM cell populations. Similar to skeletal myoblasts, these BMderived stem cells can be readily harvested and isolated based on their expression of surface markers and expanded ex vivo for autologous transplantation without any immune 


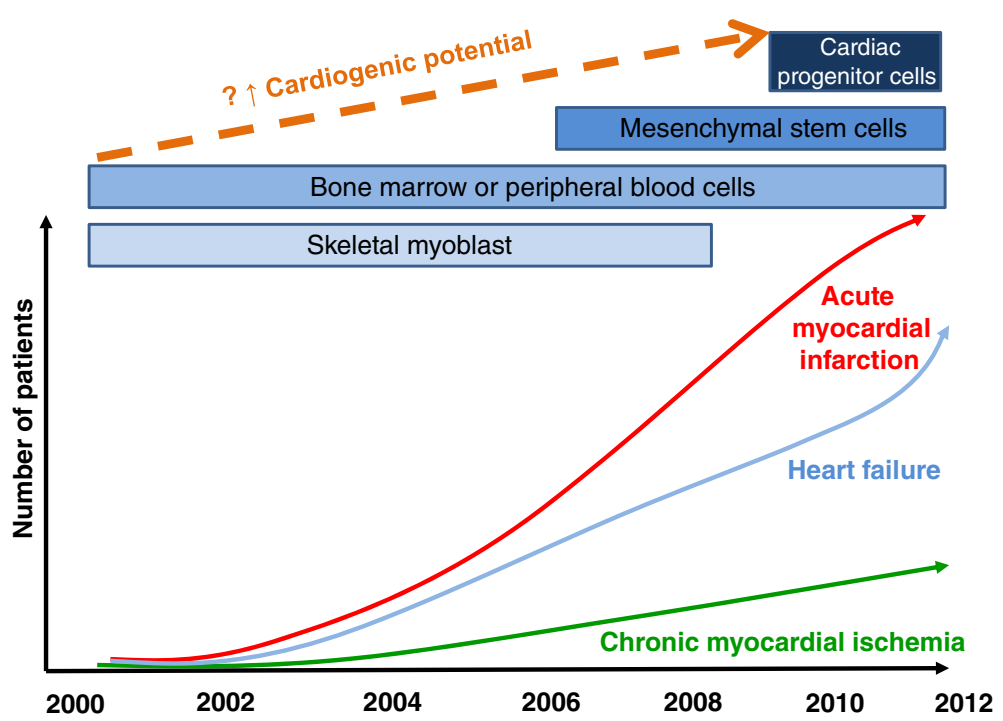

Figure 2 Overview of the types of adult stem cells being investigated for the treatment of acute myocardial infarction, chronic myocardial ischemia and heart failure.

rejection. HSCs and EPCs can be isolated from BM cells through selective sorting for a particular set of surface antigens, including Lin $^{-} \mathrm{c}-\mathrm{kit}^{+}, \mathrm{Sca}-\mathrm{1}^{+}, \mathrm{CD} 34, \mathrm{CD} 38, \mathrm{CD} 45$, CD133, and KDR [14-16]; MSCs can be isolated and expanded easily from BM cells due to their ability to adhere to culture dishes, and can be further characterized by their expression of CD44, CD54 and CD105 [17,18]. In vitro experiments have shown that these BM-derived stem cells are able to trans-differentiate into various cell types, including neurons, hepatocytes, skeletal muscles and cardiomyocytes under appropriate culture conditions [19,20]. Experimental studies suggested that transplantation of unselected BMderived cells or selected HSCs, EPCs or MSCs into the acute or chronic ischemic myocardium result in various degrees of in vivo neo-angiogenesis, and improvement in cardiac function. As discussed above, indirect actions, such as paracrine effects, rather than direct cardiac transdifferentiation of these BM-derived cells, are likely the major mechanism for the improvement of cardiac function after transplantation. The encouraging results from preclinical studies with different types of BM-derived cells (including mononuclear BM cells, HSCs, EPCs and MSCs) resulted in a series of pilot clinical trials investigating the potential therapeutic use of these BM-derived cells in patients with acute MI, chronic myocardial ischemia and HF (Figure 2). Despite the high degree of heterogeneity in terms of cell population, dose, preparation and delivery methods, meta-analysis of these clinical trials [21,22] did suggest that transplantation of these BM-derived cells is remarkably safe, has modest effects with regard to reducing LV dysfunction and remodeling after acute MI, and improves symptoms in patients with chronic myocardial ischemia. On the other hand, the clinical efficacy of these
BM-derived stem cells in patients with more severe LV dysfunction after MI [23] or chronic HF [24] appears to be less impressive or negative. This is likely attributed to their poor direct cardiogenic potential to achieve true myocardial regeneration in the setting of severe LV dysfunction. Furthermore, the therapeutic effects of BM-derived cells for autologous transplantation are also limited by the reduction in their numbers as well as impairment of proliferation and function associated with ageing and co-morbidities in patients with cardiovascular diseases [25,26]. Therefore, it is challenging to yield sufficient functional BM-derived stem cells via direct isolation or ex-vivo expansion for transplantation (Figure 3).

Currently, there are very limited data directly comparing safety and efficacy between these different types of BMderived cells for therapeutic use. Nevertheless, emerging data suggest that more selected populations of these BMderived stem cells, such as CD34(+) EPCs or MSCs, rather than BM mononuclear cells or HSCs, might have better therapeutic efficacy $[27,28]$.

\section{Endothelial progenitor cells}

By definition, EPCs represent a subset of progenitor cells that circulate in the BM and peripheral blood that have the ability to differentiate into endothelial cells. EPCs are mobilized from the BM into the peripheral circulation in response to stress as well as hematopoietic growth factors and thus can be collected for therapeutic use with an apheresis system based on their expression of surface markers, such as CD34 and CD133 [28]. Although isolation of EPCs from peripheral blood is less invasive than direct BM cell harvesting, the number of EPCs obtained is lower, and is associated with the cost and potential side effects 


\section{Multipotent (adult) stem cells}

\section{Pros}

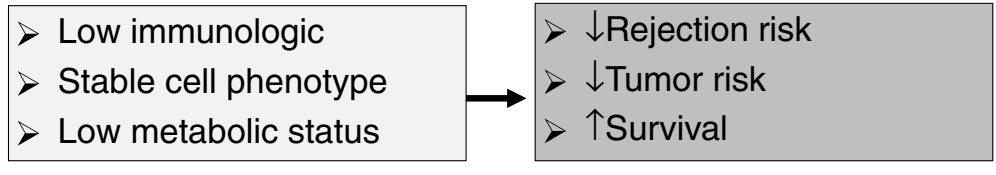

\section{Cons}
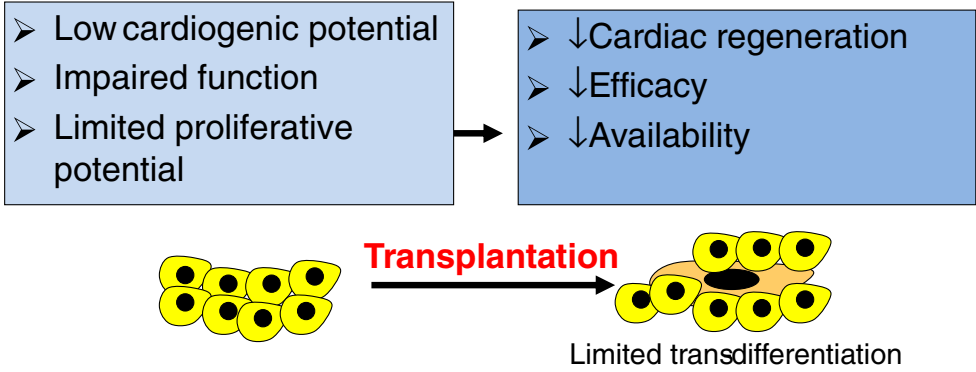

Figure 3 Pros and cons of adult (multipotent) stem cells for heart regeneration.

related to the use of growth factors. While the therapeutic effects of EPCs might be better than those with nonselected BM cells, these share a lot of limitations as therapeutic agents, such as reduced numbers and functional capacity of EPCs in patients with cardiovascular diseases, and a very limited capacity for ex vivo expansion to yield sufficient numbers for transplantation $[25,26]$.

\section{Mesenchymal stem cells}

MSCs are a subset of stem cells from the stroma of BM as well as other sources, such as adipose tissues, cord blood and placenta, that are positive for CD44, CD54 and CD105, but negative for HSC markers CD34 and CD133. In the $\mathrm{BM}$, they account for only about $0.01 \%$ of the BM mononuclear cell fraction. MSCs can be isolated and expanded easily from $\mathrm{BM}$ or other sources due to their ability to adhere to culture dishes $[17,18]$. MSCs are denoted by their ability to differentiate into cells of the mesenchymal lineage. However, many studies have reported that MSCs also have pluripotent plasticity and are able to differentiate into other somatic cell types in vitro, including cardiomyocytes [29,30]. Indeed, preclinical studies in animal models of MI have demonstrated that transplanted MSCs have the potential to differentiate into cardiomyocytes [31], smooth muscle cells [32] and endothelial cells [33]. Moreover, experimental studies have shown that MSC transplantation can induce angiogenesis in ischemic myocardium and improves myocardial function [34,35]. Pilot clinical trials showed that autologous MSCs could improve cardiac function in patients with acute MI [36,37] and HF [38]. Furthermore, these cells possess low potential for immune rejection due to the low level of expression of class II major histocompatibility complex II antigen and can inhibit the proliferation and function of immune cells, such as T cells, B cells, natural killer cells and dendritic cells $[39,40]$. Therefore, MSCs may be used as a cost-effective 'off-the-shelf' allogeneic cell source for the treatment of MI and HF. Indeed, recent studies [41] have shown that allogeneic MSCs are as effective as autologous MSCs for the treatment of acute MI. Therefore, there is a growing interest in using MSCs as a therapeutic agent for heart regeneration as they can be more easily obtained from different sources than other stem cells, expanded ex vivo to yield sufficient numbers and used in autologous or allogeneic fashion for transplantation (Figure 2). While their ability to transdifferentiate into cardiomyocytes seems to be as low as other BM-derived cells, priming of autologous MSCs to enhance their cardiogenic potential using a cocktail of growth factors is safe and feasible, and can improve functional class and LV function in patients with ischemic cardiomyopathy [42]. Whether this approach can enhance true direct regeneration of cardiomyocytes via the transplanted modified MSCs needs further investigation. Furthermore, the relative therapeutic efficacy of MSCs derived from different sources for heart regeneration is also unclear. Recent studies suggest that MSCs derived from pluripotent stem cells such as ESCs [43] or iPSCs [44] are superior to BM-derived MSCs for tissue repair.

\section{Cardiac stem cells}

While the heart has been considered to be a terminally differentiated organ, different populations of endogenous CSCs in low numbers have recently been identified in adult mammalian heart [2]. Different populations of CSCs residing in the myocardium can be classified based on their phenotypes (cardiospheres and cardiac side population cells) or 
expression of surface markers, including c-kit ${ }^{+}, \mathrm{sca}-1^{+}$, and Isl $1^{+}$, and their ability to differentiate into functional cardiomyocytes in culture [45]. These resident CSCs can be obtained from surgical and endomyocardial biopsy, and expanded ex vivo for autologous transplantation. In experimental models of MI, transplanted or mobilized resident CSCs can engraft and acquire cardiac and vascular phenotypes in infarcted myocardium to improve myocardial perfusion and LV function [46,47].

Pilot clinical trials with intracoronary infusion of autologous cardiospheres [48] and c-kit ${ }^{+}$CSCs [49] in patients with ischemic cardiomyopathy have demonstrated that transplantation of these CSCs was safe and had potential beneficial therapeutic effects. While it has been proposed that these CSCs are more cardiogenic and have potential to achieve direct heart regeneration (Figure 2), available results from these pilot clinical trials did not convincingly demonstrate sufficient heart regeneration due to the modest [48] or lack [49] of sufficient improvement of LV function after transplantation. Although cardiac magnetic resonance imaging in these studies showed increased viable myocardium at targeted regions after transplantation, the relative contributions of direct trans-differentiation to cardiomyocytes versus myocardial repair via indirect mechanisms after CSC transplantation remain unclear (Figure 1). Similar to other adult stem cells, the poor engraftment and survival of CSCs after transplantation remain major issues. Furthermore, the relative therapeutic efficacies of different populations of CSCs for heart regeneration are also unclear [50].

\section{Future roadmap for adult stem cells}

Currently, several types of adult stem cells, including BMderived cells, MSCs and CSCs, are being investigated for the treatment of acute MI, chronic myocardial ischemia and HF (Figure 2). The relative accessibility and lack of immune rejection of these autologous cells make their translation from preclinical to clinical studies easy. Overall, transplantation of these adult stem cells is feasible and remarkably safe, without evidence of tumor formation or proarrhythmias, except for skeletal myoblasts. Unfortunately, skeletal myoblasts failed to fulfill the initial promise of heart regeneration with only modest or no improvement in LV function and clinical outcomes. Several major ongoing trials (Table 1) will try to address whether the use of BM mononuclear cells can improve clinical outcome and reduce mortality in patients with acute MI. The majority of the trials used autologous BM or MSCs in patients with acute MI or ischemic cardiomyopathy. Moreover, both intracoronary and intramyocardial injection of those cells is being tested. In general, the major shortcomings of these adult stem cells include limited cardiogenic potential, low proliferative ability, poor engraftment and survival after transplantation, and reduced numbers and function in sick patients with severe cardiovascular diseases (Figure 3). As a result, alternative cell types, such as MSCs or cardiac stem cells derived from allogeneic and non-BM sources, such as adipose tissue and umbilical cord, and modified MSCs or cardiac stem cells, which have been proposed to have superior therapeutic efficacy to autologous BM-derived cells, are also under clinical investigation (Table 1). Currently, MSCs and CSCs seem to be the most promising adult multipotent stem cell therapy. Nevertheless, the optimal cell type, methods and timing of delivery and mechanisms of action need to be further investigated. Moreover, various combinations of these adult stem cells may prove to be more effective than just a single stem cell type in the future [51].

\section{Pluripotent stem cells}

While adult stem cells have varying cardiogenic transdifferentiation ability, pluripotent stem cells, such as ESCs and iPSCs, have unambiguous potential for differentiation into functional cardiomyocytes. Most important, these pluripotent stem cells are able to self-renew indefinitely as an unlimited cell source for tissue regeneration. Under appropriate culture conditions with selected growth factors, both ESCs [52] and iPSCs [53] can be differentiated into cardiomyocytes in vitro. As a result, ESC- or iPSC-derived cardiomyocytes have been considered to be one of the most promising cell sources for cardiac regeneration.

\section{Embryonic stem cells}

ESCs are pluripotent cells derived from the inner cell mass of blastocysts of the developing embryo and have the ability to differentiate into derivatives of the three primary germ layers: ectoderm, endoderm and mesoderm. As the 'prototype' of pluripotent stem cells, ESCs are capable of selfrenewal and propagating themselves indefinitely under defined conditions. Because of their potentially unlimited capacity for self-renewal, ESC therapies have been proposed for regenerative medicine and tissue replacement after injury. Previous studies have shown that transplantation of murine ESC-derived cardiomyocytes can couple functionally with host cardiomyocytes, stimulate formation of new blood vessels, inhibit apoptosis and improve myocardial function in an animal model of MI [54,55]. Compared with $\mathrm{BM}$ cells, transplantation of purified ESC-derived cardiomyocytes was more effective for improving LV function after MI [56]. Similarly, preclinical studies have demonstrated that human ESC-derived cardiomyocytes can survive, proliferate and mature after transplantation to improve LV function in a mouse model of MI $[57,58]$. Furthermore, the transplanted human ESC-derived cardiomyocytes were found to be electromechanically integrated with host cardiomyocytes and reduced the risk of inducible cardiac arrhythmia without teratoma formation [59]. However, the number of engrafted ESC-derived cardiomyocytes remained small and the functional benefit observed early 
Table 1 Ongoing clinical trials on stem cell therapy for treatment of acute myocardial infarction and heart failure (Clinicaltrials.gov)

\begin{tabular}{|c|c|c|c|c|c|c|c|c|c|}
\hline $\begin{array}{l}\text { Trial name } \\
\text { (reference) }\end{array}$ & Cell type & Source & $\begin{array}{l}\text { Route } \\
\text { of delivery }\end{array}$ & Endpoint & $\begin{array}{l}\text { Phase } \\
\text { of trial }\end{array}$ & $\begin{array}{l}\text { Number } \\
\text { of patients }\end{array}$ & Disease status & $\begin{array}{l}\text { Study } \\
\text { identifier }\end{array}$ & Trial title \\
\hline $\begin{array}{l}\text { MARVEL/ } \\
\text { Warren et al. }\end{array}$ & $\begin{array}{l}\text { Skeletal } \\
\text { myoblasts }\end{array}$ & Autologous & Intramyocardial & $\begin{array}{l}\text { Safety/ } \\
\text { efficacy }\end{array}$ & $\begin{array}{l}\text { Phase I } \\
\text { and II }\end{array}$ & 170 & $\begin{array}{l}\text { Ischemic } \\
\text { cardiomyopathy }\end{array}$ & NCT00526253 & $\begin{array}{l}\text { To Assess Safety and Efficacy of Myoblast Implantation Into } \\
\text { Myocardium Post Myocardial Infarction }\end{array}$ \\
\hline $\begin{array}{l}\text { MYSTAR-5-YEAR/ } \\
\text { Mariann et al. }\end{array}$ & $\begin{array}{l}\text { BM } \\
\text { mononuclear } \\
\text { cells }\end{array}$ & Autologous & $\begin{array}{l}\text { Intramyocardial } \\
\text { and } \\
\text { intracoronary }\end{array}$ & $\begin{array}{l}\text { Safety/ } \\
\text { efficacy }\end{array}$ & $\begin{array}{l}\text { Phase I } \\
\text { and II }\end{array}$ & 60 & $\begin{array}{l}\text { Ischemic } \\
\text { cardiomyopathy }\end{array}$ & NCT01395212 & $\begin{array}{l}\text { Long-term Follow-up of Patients With Ischemic Heart Disease } \\
\text { Treated With Stem Cell Therapy }\end{array}$ \\
\hline COAT/Sandeep et al. & $\begin{array}{l}\text { BM } \\
\text { mononuclear } \\
\text { cells }\end{array}$ & Autologous & Intracoronary & $\begin{array}{l}\text { Safety/ } \\
\text { efficacy }\end{array}$ & $\begin{array}{l}\text { Phase I } \\
\text { and II }\end{array}$ & 40 & $\begin{array}{l}\text { Ischemic } \\
\text { cardiomyopathy }\end{array}$ & NCT01625949 & $\begin{array}{l}\text { Stem Cell Therapy in Patients With Myocardial Infarction and } \\
\text { Persistent Total Occlusion of Infarct Related Artery }\end{array}$ \\
\hline AMIRST/Ashok et al. & $\begin{array}{l}\text { BM } \\
\text { mononuclear } \\
\text { cells }\end{array}$ & Autologous & Intracoronary & $\begin{array}{l}\text { Safety/ } \\
\text { efficacy }\end{array}$ & $\begin{array}{l}\text { Phase I } \\
\text { and II }\end{array}$ & 30 & Acute Ml & NCT01536106 & $\begin{array}{l}\text { Rapid Delivery of Autologous Bone Marrow Derived Stem Cells } \\
\text { in Acute Myocardial Infarction Patients }\end{array}$ \\
\hline BAMI/Anthony et al. & $\begin{array}{l}\text { BM } \\
\text { mononuclear } \\
\text { cells }\end{array}$ & Autologous & Intracoronary & $\begin{array}{l}\text { Safety/ } \\
\text { efficacy }\end{array}$ & Phase III & 3,000 & Acute Ml & NCT01569178 & $\begin{array}{l}\text { The Effect of Intracoronary Reinfusion of Bone Marrow-derived } \\
\text { Mononuclear Cells (BM-MNC) on All Cause Mortality in Acute } \\
\text { Myocardial Infarction }\end{array}$ \\
\hline AMR-1/Arshed et al. & $\mathrm{BM} \mathrm{CD} 34^{+}$ & Autologous & Intracoronary & $\begin{array}{l}\text { Safety/ } \\
\text { efficacy }\end{array}$ & $\begin{array}{l}\text { Phase I } \\
\text { and II }\end{array}$ & 40 & Acute Ml & NCT00313339 & $\begin{array}{l}\text { Intra-coronary Infusion of Bone Marrow Derived Autologous } \\
\text { CD34+ Selected Cells in Patients With Acute Myocardial Infarction }\end{array}$ \\
\hline $\begin{array}{l}\text { PreSERVE-AMI/ } \\
\text { Arshed et al. }\end{array}$ & $\mathrm{BM} \mathrm{CD} 34^{+}$ & Autologous & Intracoronary & $\begin{array}{l}\text { Safety/ } \\
\text { efficacy }\end{array}$ & $\begin{array}{l}\text { Phase I } \\
\text { and II }\end{array}$ & 160 & $\begin{array}{l}\text { Ischemic } \\
\text { cardiomyopathy }\end{array}$ & NCT01495364 & $\begin{array}{l}\text { AMR-001 Versus Placebo Post ST Segment Elevation Myocardial } \\
\text { Infarction }\end{array}$ \\
\hline $\begin{array}{l}\text { NOGA-DCM/ } \\
\text { Vrtovec et al. }\end{array}$ & $\mathrm{BM} \mathrm{CD} 34^{+}$ & Autologous & $\begin{array}{l}\text { Intramyocardial } \\
\text { versus } \\
\text { intracoronary }\end{array}$ & $\begin{array}{l}\text { Safety/ } \\
\text { efficacy }\end{array}$ & $\begin{array}{l}\text { Phase I } \\
\text { and II }\end{array}$ & 90 & $\begin{array}{l}\text { Dilated } \\
\text { cardiomyopathy }\end{array}$ & NCT01350310 & $\begin{array}{l}\text { Safety and Efficacy Study of Intramyocardial Stem Cell Therapy } \\
\text { in Patients With Dilated Cardiomyopathy }\end{array}$ \\
\hline $\begin{array}{l}\text { IMPACT-CABG/ } \\
\text { Nicolas et al. }\end{array}$ & $\mathrm{BM} C D 133^{+}$ & Autologous & Intramyocardial & $\begin{array}{l}\text { Safety/ } \\
\text { efficacy }\end{array}$ & $\begin{array}{l}\text { Phase I } \\
\text { and II }\end{array}$ & 20 & $\begin{array}{l}\text { Ischemic } \\
\text { cardiomyopathy }\end{array}$ & NCT01033617 & $\begin{array}{l}\text { IMPlantation of Autologous CD133+ sTem Cells in Patients } \\
\text { Undergoing CABG }\end{array}$ \\
\hline PERFECT/Gustav et al. & $\mathrm{BM} \mathrm{CD}_{133^{+}}$ & Autologous & Intramyocardial & Efficacy & Phase II & 142 & $\begin{array}{l}\text { Ischemic } \\
\text { cardiomyopathy }\end{array}$ & NCT00950274 & $\begin{array}{l}\text { Intramyocardial Transplantation of Bone Marrow Stem Cells in } \\
\text { Addition to Coronary Artery Bypass Graft (CABG) Surgery }\end{array}$ \\
\hline SELECT-AMI/Jozef et al. & $\mathrm{BM} C D 133^{+}$ & Autologous & Intracoronary & $\begin{array}{l}\text { Safety/ } \\
\text { efficacy }\end{array}$ & $\begin{array}{l}\text { Phase I } \\
\text { and II }\end{array}$ & 60 & Acute MI & NCT00529932 & $\begin{array}{l}\text { A Trial Using CD133 Enriched Bone Marrow Cells Following } \\
\text { Primary Angioplasty for Acute Myocardial } \\
\text { Infarction }\end{array}$ \\
\hline AlsterMACS & $\mathrm{BM} C \mathrm{CD} 133^{+}$ & Autologous & $\begin{array}{l}\text { Intramyocardial } \\
\text { versus } \\
\text { intracoronary }\end{array}$ & $\begin{array}{l}\text { Safety/ } \\
\text { efficacy }\end{array}$ & $\begin{array}{l}\text { Phase I } \\
\text { and II }\end{array}$ & 64 & $\begin{array}{l}\text { Ischemic } \\
\text { cardiomyopathy }\end{array}$ & NCT01337011 & $\begin{array}{l}\text { Intra-coronary Versus Intramyocardial Application of Enriched } \\
\text { CD133pos Autologous Bone Marrow Derived Stem Cells }\end{array}$ \\
\hline $\begin{array}{l}\text { ENACT-AMI/ } \\
\text { Duncan et al. }\end{array}$ & $\begin{array}{l}\text { Endothelial } \\
\text { progenitor } \\
\text { cells }\end{array}$ & Autologous & Intracoronary & Efficacy & Phase II & 100 & Acute MI & NCT00936819 & $\begin{array}{l}\text { Enhanced Angiogenic Cell Therapy - Acute Myocardial } \\
\text { Infarction Trial }\end{array}$ \\
\hline $\begin{array}{l}\text { REPAIR-ACS/ } \\
\text { Andreas et al. }\end{array}$ & $\begin{array}{l}\text { BM derived } \\
\text { progenitor } \\
\text { cells }\end{array}$ & Autologous & Intracoronary & Efficacy & Phase II & 100 & Acute Ml & NCT00711542 & $\begin{array}{l}\text { Effects of Intracoronary Progenitor Cell Therapy on Coronary } \\
\text { Flow Reserve After Acute Ml }\end{array}$ \\
\hline $\begin{array}{l}\text { ESTIMATION/ } \\
\text { Evgeny et al. }\end{array}$ & BM MSCs & Autologous & Intramyocardial & Efficacy & Phase II & 50 & Acute Ml & NCT01394432 & $\begin{array}{l}\text { Study for Endocardial Mesenchymal Stem Cells Implantation in } \\
\text { Patients After Acute Myocardial Infarction }\end{array}$ \\
\hline Kastrup et al. & BM MSCs & Autologous & Intramyocardial & Efficacy & Phase II & 60 & $\begin{array}{l}\text { Ischemic } \\
\text { cardiomyopathy }\end{array}$ & NCT00644410 & Autologous Mesenchymal Stromal Cell Therapy in Heart Failure \\
\hline
\end{tabular}


Table 1 Ongoing clinical trials on stem cell therapy for treatment of acute myocardial infarction and heart failure (Clinicaltrials.gov) (Continued)

\begin{tabular}{|c|c|c|c|c|c|c|c|c|c|}
\hline Maskon et al. & BM MSCs & Autologous & Intracoronary & $\begin{array}{l}\text { Safety/ } \\
\text { efficacy }\end{array}$ & $\begin{array}{l}\text { Phase I } \\
\text { and II }\end{array}$ & 80 & $\begin{array}{l}\text { Ischemic } \\
\text { cardiomyopathy }\end{array}$ & NCT01720888 & $\begin{array}{l}\text { Intracoronary Autologous Mesenchymal Stem Cells Implantation } \\
\text { in Patients With Ischemic Dilated Cardiomyopathy }\end{array}$ \\
\hline RELIEF/Yang et al. & BM MSCs & Autologous & Intracoronary & $\begin{array}{l}\text { Safety/ } \\
\text { efficacy }\end{array}$ & $\begin{array}{l}\text { Phase I } \\
\text { and II }\end{array}$ & 135 & Acute Ml & NCT01652209 & $\begin{array}{l}\text { A Randomized, Open labEled, muLticenter Trial for Safety and } \\
\text { Efficacy of Intracoronary Adult Human Mesenchymal stEm Cells } \\
\text { Acute Myocardial inFarction }\end{array}$ \\
\hline MESAMI/ Jerome et al. & BM MSCs & Autologous & Intramyocardial & Safety & Phase I & 10 & $\begin{array}{l}\text { Ischemic } \\
\text { cardiomyopathy }\end{array}$ & NCT01076920 & Mesenchymal Stem Cells and Myocardial Ischemia \\
\hline $\begin{array}{l}\text { PoseidonDCM/ } \\
\text { Joshua et al. }\end{array}$ & BM MSCs & $\begin{array}{l}\text { Allogeneic } \\
\text { versus } \\
\text { autologous }\end{array}$ & Intramyocardial & $\begin{array}{l}\text { Safety/ } \\
\text { efficacy }\end{array}$ & $\begin{array}{l}\text { Phase I } \\
\text { and II }\end{array}$ & 36 & $\begin{array}{l}\text { Dilated } \\
\text { cardiomyopathy }\end{array}$ & NCT01392625 & $\begin{array}{l}\text { PercutaneOus StEm Cell Injection Delivery Effects On } \\
\text { Neomyogenesis in Dilated CardioMyopathy }\end{array}$ \\
\hline Perin et al. & $\begin{array}{l}\text { Mesenchymal } \\
\text { precursor cells }\end{array}$ & Allogeneic & Intramyocardial & $\begin{array}{l}\text { Safety/ } \\
\text { efficacy }\end{array}$ & $\begin{array}{l}\text { Phase I } \\
\text { and II }\end{array}$ & 25 & $\begin{array}{l}\text { Ischemic } \\
\text { cardiomyopathy }\end{array}$ & NCT00555828 & $\begin{array}{l}\text { Safety Study of Allogeneic Mesenchymal Precursor Cells (MPCs) } \\
\text { in Subjects With Recent Acute Myocardial Infarction }\end{array}$ \\
\hline $\mathrm{AMICl}$ Eric et al. & $\begin{array}{l}\text { Mesenchymal } \\
\text { precursor cells }\end{array}$ & Allogeneic & Intracoronary & $\begin{array}{l}\text { Safety/ } \\
\text { efficacy }\end{array}$ & $\begin{array}{l}\text { Phase I } \\
\text { and II }\end{array}$ & 225 & Acute Ml & NCT01781390 & $\begin{array}{l}\text { Safety Study of Allogeneic Mesenchymal Precursor Cell Infusion } \\
\text { in MyoCardial Infarction }\end{array}$ \\
\hline $\begin{array}{l}\text { MyStromalCell/ } \\
\text { Kastrup et al. }\end{array}$ & Adipose MSCs & Autologous & Intramyocardial & Efficacy & Phase II & 60 & $\begin{array}{l}\text { Ischemic } \\
\text { cardiomyopathy }\end{array}$ & NCT01449032 & $\begin{array}{l}\text { MesenchYmal STROMAL CELL Therapy in Patients With Chronic } \\
\text { Myocardial Ischemia }\end{array}$ \\
\hline ATHENA/Perin et al. & Adipose MSCs & Autologous & Intramyocardial & $\begin{array}{l}\text { Safety/ } \\
\text { efficacy }\end{array}$ & $\begin{array}{l}\text { Phase I } \\
\text { and II }\end{array}$ & 45 & $\begin{array}{l}\text { Ischemic } \\
\text { cardiomyopathy }\end{array}$ & NCT01556022 & $\begin{array}{l}\text { Safety and Feasibility Trial of Adipose-Derived Regenerative Cells } \\
\text { in the Treatment of Chronic Myocardial Ischemia }\end{array}$ \\
\hline $\begin{array}{l}\text { PRECISE/ } \\
\text { Fernández-Avilés et al. }\end{array}$ & Adipose MSCs & Autologous & Intramyocardial & $\begin{array}{l}\text { Safety/ } \\
\text { efficacy }\end{array}$ & $\begin{array}{l}\text { Phase I } \\
\text { and II }\end{array}$ & 36 & $\begin{array}{l}\text { Ischemic } \\
\text { cardiomyopathy }\end{array}$ & NCT00426868 & $\begin{array}{l}\text { A Randomized Clinical Trial of adiPose-deRived stEm and } \\
\text { Regenerative Cells In the Treatment of Patients With Non } \\
\text { revaScularizable ischEmic Myocardium }\end{array}$ \\
\hline $\begin{array}{l}\text { APOLLO/ } \\
\text { Serruys et al. }\end{array}$ & Adipose MSCs & Autologous & Intramyocardial & $\begin{array}{l}\text { Safety/ } \\
\text { efficacy }\end{array}$ & $\begin{array}{l}\text { Phase I } \\
\text { and II }\end{array}$ & 48 & Acute Ml & NCT00442806 & $\begin{array}{l}\text { A Randomized Clinical Trial of AdiPOse-derived Stem ceLLs in } \\
\text { the Treatment of Patients With ST-elevation myOcardial } \\
\text { Infarction }\end{array}$ \\
\hline RIMECARD & $\begin{array}{l}\text { Umbilical cord } \\
\text { MSCs }\end{array}$ & Allogeneic & Intravenous & $\begin{array}{l}\text { Safety/ } \\
\text { efficacy }\end{array}$ & $\begin{array}{l}\text { Phase I } \\
\text { and II }\end{array}$ & 30 & $\begin{array}{l}\text { Ischemic } \\
\text { cardiomyopathy }\end{array}$ & NCT01739777 & $\begin{array}{l}\text { Randomized Clinical Trial of Intravenous Infusion Umbilical Cord } \\
\text { Mesenchymal Stem Cells on Cardiopathy }\end{array}$ \\
\hline CHART-1/Terzic et al. & $\begin{array}{l}\text { BM MSC } \\
\text { cardiopoietic } \\
\text { cells }\end{array}$ & Autologous & Intramyocardial & $\begin{array}{l}\text { Safety/ } \\
\text { efficacy }\end{array}$ & $\begin{array}{l}\text { Phase I } \\
\text { and II }\end{array}$ & 240 & $\begin{array}{l}\text { Ischemic } \\
\text { cardiomyopathy }\end{array}$ & NCT01768702 & $\begin{array}{l}\text { Safety and Efficacy of Autologous Cardiopoietic Cells for } \\
\text { Treatment of Ischemic Heart Failure }\end{array}$ \\
\hline $\begin{array}{l}\text { RECONSTRUCT/ } \\
\text { Marban et al. }\end{array}$ & $\begin{array}{l}\text { Cardiosphere- } \\
\text { derived cells }\end{array}$ & Autologous & Intramyocardial & $\begin{array}{l}\text { Safety/ } \\
\text { efficacy }\end{array}$ & $\begin{array}{l}\text { Phase I } \\
\text { and II }\end{array}$ & 24 & $\begin{array}{l}\text { Ischemic } \\
\text { cardiomyopathy }\end{array}$ & NCT01496209 & $\begin{array}{l}\text { REgenerative CardiOsphere iNjection to STRengthen } \\
\text { dysfUnCTional Hearts }\end{array}$ \\
\hline ALLSTAR/Smith et al. & $\begin{array}{l}\text { Cardiosphere- } \\
\text { derived cells }\end{array}$ & Allogeneic & Intracoronary & $\begin{array}{l}\text { Safety/ } \\
\text { efficacy }\end{array}$ & $\begin{array}{l}\text { Phase I } \\
\text { and II }\end{array}$ & 274 & $\begin{array}{l}\text { Ischemic } \\
\text { cardiomyopathy }\end{array}$ & NCT01458405 & Allogeneic Heart Stem Cells to Achieve Myocardial Regeneration \\
\hline Gourabi et al. & $\begin{array}{l}\text { Cardiac stem } \\
\text { cells }\end{array}$ & Autologous & Intracoronary & $\begin{array}{l}\text { Safety/ } \\
\text { efficacy }\end{array}$ & $\begin{array}{l}\text { Phase I } \\
\text { and II }\end{array}$ & 50 & $\begin{array}{l}\text { Ischemic } \\
\text { cardiomyopathy }\end{array}$ & NCT01758406 & $\begin{array}{l}\text { Transplantation of Autologous Cardiac Stem Cells in } \\
\text { Ischemic Heart Failure }\end{array}$ \\
\hline MESS/Mariann et al. & $\begin{array}{l}\text { Cardiac stem } \\
\text { cells }\end{array}$ & Autologous & Intracoronary & $\begin{array}{l}\text { Safety/ } \\
\text { efficacy }\end{array}$ & Phase III & 1,000 & $\begin{array}{l}\text { Ischemic } \\
\text { cardiomyopathy }\end{array}$ & NCT01098591 & Meta-analysis of Cardiac Stem Cell Studies \\
\hline
\end{tabular}

$\mathrm{BM}$, bone marrow; Ml, myocardial infarction; MSC, mesenchymal stem cell. 
after transplantation of human ESC-derived cardiomyocytes was not sustained over long-term follow-up [58,60].

Nevertheless, there are several major concerns related to the clinical application of human ESC-based therapies. First, there are relevant ethical and regulatory issues that need to be addressed. Second, despite the lack of teratoma formation in animals, the potential risk of tumorigenicity after transplanting a large number of human ESC-derived cardiomyocytes remains unclear. It is a major challenge to produce clinical grade, high purity ESC-derived cardiomyocytes as transplanting undifferentiated ESCs carries the risk of teratoma formation [61]. Third, as ESC-derived cardiomyocytes are allogeneic cells, long-term immunosuppression will be required. Moreover, the long-term survival rate of these isolated transplanted cellular grafts, even with the use of immunosuppression, is unknown. Fourth, the heterogeneous phenotypes and maturity of ESC-derived cardiomyocytes can be problematic. Compared with adult mature cardiomyocytes, ESC-derived cardiomyocytes comprise a mixed cell population, such as nodal, atrial and ventricular phenotypes [52], as well as immature electrophysiological properties, including lengthened action duration and depolarized resting membrane potential [5,52]. Transplantation of these mixed populations of immature cardiomyocytes with spontaneous electrical activity might induce cardiac arrhythmias early after transplantation before they are fully matured and integrated in vivo with host cardiomyocytes $[62,63]$.

\section{Induced pluripotent stem cells}

Recent breakthroughs in the generation of pluripotent iPSCs via 'forced' expression of specific genes (Oct $3 / 4$, Sox2, Klf4, c-Myc or Oct3/4, Sox2, Nanog, Lin28) in somatic cells $[64,65]$ might overcome some of the limitations of human ESCs for heart regeneration. As iPSCs are generated from human somatic cells there are no ethical dilemmas as with human ESCs, and they can theoretically provide autologous cells for transplantation without the need for immunosuppression. Similar to ESCs, iPSCs are pluripotent stem cells that can be differentiated into cell types from all three germ layers in vitro. Indeed, iPSCs can also be differentiated into functional cardiomyocytes and have similar therapeutic efficacy as ESC-derived cardiomyocytes for heart regeneration. After transplantation into the animal model of MI, iPSC-derived cardiomyocytes were able to survive and integrate with host myocardium to improve LV function and attenuate LV dilatation [66,67]. However, iPSCs appear to be more tumorigenic than ESCs and produced massive teratomas after transplantation into immune-deficient hosts $[68,69]$. Similar to ESCs, the ability to differentiate and purify these iPSC-derived cardiomyocytes to reduce the risk of teratoma formation is critical for future development of iPSC-based therapy. Moreover, the use of viral vectors in the reprogramming procedure may result in mutagenesis or malignant transformation. As a result, it is important to optimize other methods for reprogramming, such as gene delivery via non-integrating viruses, plasmid DNA or recombinant DNA, before clinic applications [70,71].

\section{Future roadmap for pluripotent stem cells}

As discussed above, only ESCs or iPSCs are pluripotent stem cells that possess the ability to produce sufficient amounts of functional cardiomyocytes on a large scale for 'true' heart regeneration (Figure 4). On the other hand, the risks of using ESC- or iPSC-derived cardiomyocytes in the clinic are much higher than with adult stem cells due to the potential risk of tumorigenicity and proarrhythmias. Several main hurdles need to be addressed before their clinical application. First, further development of differentiation protocols to yield high purity (100\%) functional cardiomyocytes at large scales (tens to hundreds of billions) without the need for any genetic modification for sorting is needed. Second, future studies are needed to determine the optimal degree of maturation of ESC- or iPSC-derived cardiomyocytes for transplantation. While heterogeneous and immature electrical phenotypes of these cells might contribute to proarrhythmias, fully mature cardiomyocytes have poor survival and engraftment after transplantation [72]. Third, the substantial cost associated with generation of clinical grade ESC or iPSC lines, as well as their differentiation and purification under good clinical practice at large scales, will limit their feasibility as cell sources for heart regeneration in the majority of patients. Fourth, future strategies are needed to address the issue of poor engraftment and survival of these cells after transplantation, as with adult stem cells. Finally, other than the potential application of iPSCs for cardiac regeneration, they have been proposed as an in vitro platform for specific drug screening and testing.

The preliminary characterization of iPSC-derived cardiomyocytes and their validation with over 40 drugs of known activity suggests that these cells could serve as a new tool to develop pharmacologically relevant in vitro screens to detect cardiotoxicity while improving patient safety and reducing the economic burden of drug attrition [73,74].

\section{New strategies to improve stem cell survival and engraftment}

As discussed above, the major roadblocks for the clinical application of both adult stem cells and pluripotent stem cells are significant cell death and apoptosis, lack of cell engraftment, and poor differentiation after transplantation. Prior studies have shown that only less than $10 \%$ of the BM cells were detected in the infarcted myocardium within 2 hours after injection [75,76]. Similarly, only a very small proportion of ESC-derived cardiomyocytes could be observed in the infarcted myocardium 


\section{Pluripotent stem cells}

\section{Pros}
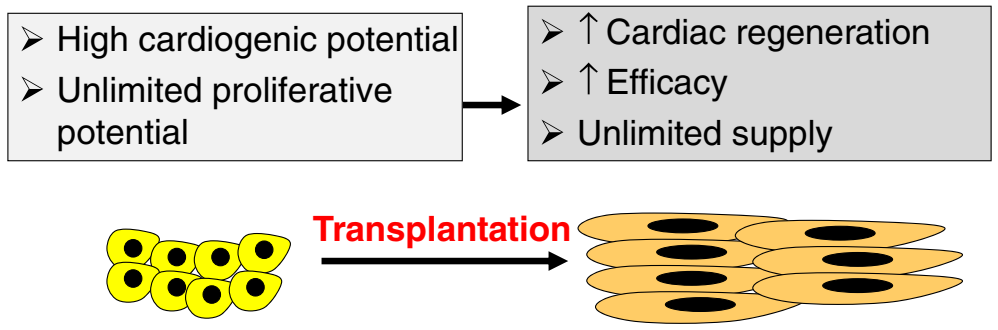

Cons

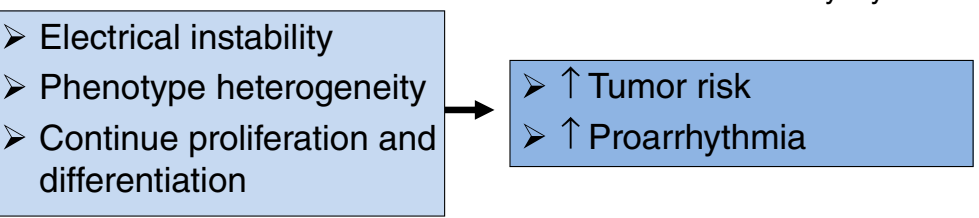

Figure 4 Pros and cons of pluripotent stem cells for heart regeneration.

after transplantation [62]. Furthermore, in post-infarcted heart, both adult cardiomyocytes and the surrounding extracellular matrix, which provides support to the cardiomyocytes, are destroyed. Therefore, it is likely that the inflammatory milieu of the ischemic environment and the lack of extracellular matrix may be the major reason for cell death after transplantation. Currently, a number of different strategies have been proposed to enhance cell survival and engraftment by ischemic preconditioning and transgenic overexpression of antiapoptotic factors (for example, stromal derived factor- $1 \alpha$ and insulin-like growth factor-1) [77,78] and prosurvival and pro-angiogenic factors (for example, Akt and vascular endothelial growth factor) $[79,80]$.

Another approach is via cardiac tissue engineering by combining scaffold materials and cells to optimize cell survival and engraftment [81,82]. It is likely that these transplanted cells will require a supportive biochemical, physical, and spatial environment for optimal survival that allows them to differentiate and integrate with the infarcted myocardium. Common cardiac tissue engineering strategies include an engineered 'vehicle' that facilitates cell growth and proliferation. This may be a scaffold, a patch or cell sheet made of either natural or synthetic polymeric materials similar to the native extracellular matrix, such as gelatin, collagen, fibrin, Matrigel, alginate and poly (lacticco-glycolic acid). Moreover, these 'vehicles' also provide mechanical support to ventricular chamber integrity in order to limit ventricular wall dilatation, and thus provide a favorable environment for the transplanted cells to enhance cell survival, proliferation and differentiation. The ideal materials should also be biodegradable and nonimmunogenic.
In general, cardiac tissue engineering can be achieved via either in vitro or in vivo approaches. In the in vitro approach, cardiac tissue engineering consists of in vitro generation of a cellular patch by seeding cells on scaffolds or patches that are then attached on the epicardial surface of the myocardium. The advantage of in vitro cardiac tissue engineering is the possibility of controlling the shape and size of the constructs and improving viability of the seeded cells. The main limitation of this approach is that implantation of these materials involves an invasive open-chest procedure and the implanted patches may affect the electrical and mechanical properties of the host myocardium if they fail to integrate. For in vivo cardiac tissue engineering, a mixture of biomaterials and transplanted cells is injected into the damaged myocardium. The advantage of this approach is that it is minimally invasive without the need for major surgery. On the other hand, the growth and differentiation of the transplanted cells in the biomaterial cannot be controlled or optimized before transplantation. Nevertheless, both in vitro and in vivo cardiac tissue engineering using BM stem cells [83], CSCs [84] and ESC-derived cardiomyocytes [85] have been shown to increase cell engraftment, enhance angiogenesis and improve LV function after transplantation.

\section{Future perspectives of stem cell therapy for heart regeneration}

Stem cell therapy is a promising therapeutic approach for the treatment of HF. It is still at an early stage of development, however, and many issues remain to be addressed. Preclinical studies and pilot clinical trials have revealed many limitations of current stem cell therapies based 
mainly on adult stem cells, including significant cell death and apoptosis, lack of cell engraftment, and limited heart regeneration after cell transplantation. Both adult and pluripotent stem cells have their own advantages and disadvantages as cell sources for heart regeneration. Although no major safety concerns were raised during initial clinical trials using autologous adult stem cells, potential adverse side effects, such as the risk of proarrhythmia and tumor formation, need to be carefully monitored if we intend to use allogeneic and pluripotent stem cells in the future. Furthermore, strategies that improve therapeutic efficacy as well as cellular survival and engraftment, such as modified stem cells, mixed stem cells and cardiac tissue engineering, are under development. Finally, techniques that can induce trans-differentiation of somatic cells directly into functional cardiomyocytes in vitro and in vivo have also been developed recently, and may be proven to be a more effective strategy for promoting endogenous heart regeneration rather than transplanting exogenous stem cells in the future [86].

Note: This article is part of a thematic series on Cardiovascular regeneration edited by Ronald Li. Other articles in the series can be found online at http://stemcellres.com/series/cardiovascular.

\section{Abbreviations}

BM: Bone marrow; CSC: Cardiac stem cell; EPC: Endothelial progenitor cell; ESC: Embryonic stem cell; HF: Heart failure; HSC: Hematopoietic stem cell; iPSC: Induced pluripotent stem cell; LV: Left ventricular; MI: Myocardial infarction; MSC: Mesenchymal stem cell.

\section{Competing interests}

The authors declare that they have no competing interests.

\section{Acknowledgements}

This study was supported by the General Research Fund (No. HKU 7801/10 M, HKU 7811/11 M, HKU 7795/12 M); the Collaborative Research Fund (HKU 8/CRF/09); and the Theme-based Research Scheme (T12-705/11) of the Research Grant Council of Hong Kong.

Published: 24 Dec 2013

\section{References}

1. White HD, Chew DP: Acute myocardial infarction. Lancet 2008, 372:570-584.

2. Garbern JC, Lee RT: Cardiac stem cell therapy and the promise of heart regeneration. Cell Stem Cell 2013, 12:689-698.

3. Loffredo FS, Steinhauser ML, Gannon J, Lee RT: Bone marrow-derived cell therapy stimulates endogenous cardiomyocyte progenitors and promotes cardiac repair. Cell Stem Cell 2011, 8:389-398.

4. Li TS, Cheng K, Malliaras K, Smith RR, Zhang Y, Sun B, Matsushita N, Blusztajn A, Terrovitis J, Kusuoka H, Marban L, Marban E: Direct comparison of different stem cell types and subpopulations reveals superior paracrine potency and myocardial repair efficacy with cardiosphere-derived cells. J Am Coll Cardiol 2012, 59:942-953.

5. Liao SY, Liu Y, Siu CW, Zhang Y, Lai WH, Au KW, Lee YK, Chan YC, Yip PM, Wu EX, Wu Y, Lau CP, Li RA, Tse HF: Proarrhythmic risk of embryonic stem cell-derived cardiomyocyte transplantation in infarcted myocardium. Heart Rhythm 2010, 7:1852-1859.

6. Menasche P: Embryonic stem cells for severe heart failure: why and how? J Cardiovasc Transl Res 2012, 5:555-565.
7. Tse HF, Siu CW, Zhu SG, Songyan L, Zhang QY, Lai WH, Kwong YL, Nicholls J, Lau CP: Paracrine effects of direct intramyocardial implantation of bone marrow derived cells to enhance neovascularization in chronic ischaemic myocardium. Eur J Heart Failure 2007, 9:747-753.

8. Kocher AA, Schuster MD, Szabolcs MJ, Takuma S, Burkhoff D, Wang J, Homma S, Edwards NM, Itescu S: Neovascularization of ischemic myocardium by human bone-marrow-derived angioblasts prevents cardiomyocyte apoptosis, reduces remodeling and improves cardiac function. Nat Med 2001, 7:430-436.

9. Mias C, Lairez O, Trouche E, Roncalli J, Calise D, Seguelas MH, Ordener C, Piercecchi-Marti MD, Auge N, Salvayre AN, Bourin P, Parini A, Cussac D: Mesenchymal stem cells promote matrix metalloproteinase secretion by cardiac fibroblasts and reduce cardiac ventricular fibrosis after myocardial infarction. Stem Cells 2009, 27:2734-2743.

10. Xiong $Q$, Ye L, Zhang P, Lepley M, Swingen C, Zhang L, Kaufman DS, Zhang J: Bioenergetic and functional consequences of cellular therapy: activation of endogenous cardiovascular progenitor cells. Circ Res 2012, 111:455-468

11. Menasche P, Hagege AA, Vilquin JT, Desnos M, Abergel E, Pouzet B, Bel A, Sarateanu S, Scorsin M, Schwartz K, Bruneval P, Benbunan M, Marolleau JP, Duboc D: Autologous skeletal myoblast transplantation for severe postinfarction left ventricular dysfunction. J Am Coll Cardiol 2003, 41:1078-1083.

12. Taylor DA, Atkins BZ, Hungspreugs $P$, Jones TR, Reedy MC, Hutcheson KA, Glower $D D$, Kraus WE: Regenerating functional myocardium: improved performance after skeletal myoblast transplantation. Nat Med 1998, 4:929-933.

13. Menasche P: Stem cell therapy for heart failure: are arrhythmias a real safety concern? Circulation 2009, 119:2735-2740.

14. Spangrude GJ, Heimfeld S, Weissman IL: Purification and characterization of mouse hematopoietic stem cells. Science 1988, 241:58-62.

15. Jujo K, li M, Losordo DW: Endothelial progenitor cells in neovascularization of infarcted myocardium. J Mol Cell Cardiol 2008, 45:530-544.

16. Peichev M, Naiyer AJ, Pereira D, Zhu Z, Lane WJ, Williams M, Oz MC, Hicklin DJ, Witte L, Moore MA, Rafii S: Expression of VEGFR-2 and AC133 by circulating human CD34(+) cells identifies a population of functional endothelial precursors. Blood 2000, 95:952-958.

17. Caplan Al: Mesenchymal stem cells. J Orthopaedic Res 1991, 9:641-650.

18. Alhadlaq A, Mao Jj: Mesenchymal stem cells: isolation and therapeutics. Stem Cells Dev 2004, 13:436-448.

19. Jackson KA, Majka SM, Wang H, Pocius J, Hartley CJ, Majesky MW, Entman ML, Michael LH, Hirschi KK, Goodell MA: Regeneration of ischemic cardiac muscle and vascular endothelium by adult stem cells. J Clin Invest 2001, 107:1395-1402.

20. Pittenger MF, Mackay AM, Beck SC, Jaiswal RK, Douglas R, Mosca JD, Moorman MA, Simonetti DW, Craig S, Marshak DR: Multilineage potential of adult human mesenchymal stem cells. Science 1999, 284:143-147.

21. Jeevanantham V, Butler M, Saad A, Abdel-Latif A, Zuba-Surma EK, Dawn B: Adult bone marrow cell therapy improves survival and induces long-term improvement in cardiac parameters: a systematic review and meta-analysis. Circulation 2012, 126:551-568.

22. Clifford DM, Fisher SA, Brunskill SJ, Doree C, Mathur A, Watt S, Martin-Rendon E: Stem cell treatment for acute myocardial infarction. Cochrane Database Syst Rev 2012, 2:CD006536.

23. Rehman J: Bone marrow tinctures for cardiovascular disease: lost in translation. Circulation 2013, 127:1935-1937.

24. Perin EC, Willerson JT, Pepine CJ, Henry TD, Ellis SG, Zhao DX, Silva GV, Lai D, Thomas JD, Kronenberg MW, Martin AD, Anderson RD, Traverse JH, Penn MS, Anwaruddin S, Hatzopoulos AK, Gee AP, Taylor DA, Cogle CR, Smith D, Westbrook L, Chen J, Handberg E, Olson RE, Geither C, Bowman S, Francescon J, Baraniuk S, Piller LB, Simpson LM, et al: Effect of transendocardial delivery of autologous bone marrow mononuclear cells on functional capacity, left ventricular function, and perfusion in chronic heart failure: the FOCUS-CCTRN trial. JAMA 2012, 307:1717-1726.

25. Vasa M, Fichtlscherer S, Aicher A, Adler K, Urbich C, Martin H, Zeiher AM, Dimmeler S: Number and migratory activity of circulating endothelial progenitor cells inversely correlate with risk factors for coronary artery disease. Circ Res 2001, 89:E1-E7.

26. Imanishi T, Moriwaki C, Hano T, Nishio I: Endothelial progenitor cell senescence is accelerated in both experimental hypertensive rats and patients with essential hypertension. J Hypertension 2005, 23:1831-1837.

27. Deutsch MA, Sturzu A, Wu SM: At a crossroad: cell therapy for cardiac repair. Circ Res 2013, 112:884-890. 
28. Poole JC, Quyyumi AA: Progenitor cell therapy to treat acute myocardial infarction: the promise of high-dose autologous CD34(+) bone marrow mononuclear cells. Stem Cells Int 2013, 2013:658480.

29. Makino S, Fukuda K, Miyoshi S, Konishi F, Kodama H, Pan J, Sano M, Takahashi T, Hori S, Abe H, Hata J, Umezawa A, Ogawa S: Cardiomyocytes can be generated from marrow stromal cells in vitro. J Clin Invest 1999, 103:697-705.

30. Xu W, Zhang X, Qian H, Zhu W, Sun X, Hu J, Zhou H, Chen Y: Mesenchymal stem cells from adult human bone marrow differentiate into a cardiomyocyte phenotype in vitro. Exp Biol Med 2004, 229:623-631.

31. Toma C, Pittenger MF, Cahill KS, Byrne BJ, Kessler PD: Human mesenchymal stem cells differentiate to a cardiomyocyte phenotype in the adult murine heart. Circulation 2002, 105:93-98

32. Wang $T, X u Z$, Jiang W, Ma A: Cell-to-cell contact induces mesenchymal stem cell to differentiate into cardiomyocyte and smooth muscle cell. Int J Cardiol 2006, 109:74-81.

33. Silva GV, Litovsky S, Assad JA, Sousa AL, Martin BJ, Vela D, Coulter SC, Lin J, Ober J, Vaughn WK, Branco RV, Oliveira EM, He R, Geng YJ, Willerson JT, Perin EC: Mesenchymal stem cells differentiate into an endothelial phenotype, enhance vascular density, and improve heart function in a canine chronic ischemia model. Circulation 2005, 111:150-156.

34. Behfar A, Yamada S, Crespo-Diaz R, Nesbitt JJ, Rowe LA, Perez-Terzic C, Gaussin V, Homsy C, Bartunek J, Terzic A: Guided cardiopoiesis enhances therapeutic benefit of bone marrow human mesenchymal stem cells in chronic myocardial infarction. J Am Coll Cardiol 2010, 56:721-734.

35. Arminan A, Gandia C, Garcia-Verdugo JM, Lledo E, Trigueros C, Ruiz-Sauri A, Minana MD, Solves P, Paya R, Montero JA, Sepulveda P: Mesenchymal stem cells provide better results than hematopoietic precursors for the treatment of myocardial infarction. J Am Coll Cardiol 2010, 55:2244-2253.

36. Chen SL, Fang WW, Ye F, Liu YH, Qian J, Shan SJ, Zhang JJ, Chunhua RZ, Liao LM, Lin S, Sun JP: Effect on left ventricular function of intracoronary transplantation of autologous bone marrow mesenchymal stem cell in patients with acute myocardial infarction. Am J Cardiol 2004, 94:92-95.

37. Hare JM, Traverse JH, Henry TD, Dib N, Strumpf RK, Schulman SP, Gerstenblith G, DeMaria AN, Denktas AE, Gammon RS, Hermiller JB Jr, Reisman MA, Schaer GL, Sherman W: A randomized, double-blind, placebo-controlled, dose-escalation study of intravenous adult human mesenchymal stem cells (prochymal) after acute myocardial infarction. J Am Coll Cardiol 2009, 54:2277-2286.

38. Williams AR, Trachtenberg B, Velazquez DL, McNiece I, Altman P, Rouy D, Mendizabal AM, Pattany PM, Lopera GA, Fishman J, Zambrano JP, Heldman AW, Hare JM: Intramyocardial stem cell injection in patients with ischemic cardiomyopathy: functional recovery and reverse remodeling. Circ Res 2011, 108:792-796.

39. Kaplan JM, Youd ME, Lodie TA: Immunomodulatory activity of mesenchymal stem cells. Curr Stem Cell Res Ther 2011, 6:297-316.

40. De Miquel MP, Fuentes-Julian S, Blazquez-Martinez A, Pascual CY, Aller MA Arias J, Arnalich-Montiel F: Immunosuppressive properties of mesenchymal stem cells: advances and applications. Curr Mol Med 2012, 12:574-591.

41. Hare JM, Fishman JE, Gerstenblith G, DiFede Velazquez DL, Zambrano JP, Suncion VY, Tracy M, Ghersin E, Johnston PV, Brinker JA, Breton E, DavisSproul J, Schulman IH, Byrnes J, Mendizabal AM, Lowery MH, Rouy D, Altman P, Wong Po Foo C, Ruiz P, Amador A, Da Silva J, McNiece IK, Heldman AW: Comparison of allogeneic vs autologous bone marrowderived mesenchymal stem cells delivered by transendocardial injection in patients with ischemic cardiomyopathy: the POSEIDON randomized trial. JAMA 2012, 308:2369-2379.

42. Bartunek J, Behfar A, Dolatabadi D, Vanderheyden M, Ostojic M, Dens J, El Nakadi B, Banovic M, Beleslin B, Vrolix M, Legrand V, Vrints C, Vanoverschelde JL, Crespo-Diaz R, Homsy C, Tendera M, Waldman S, Wijns W, Terzic A: Cardiopoietic stem cell therapy in heart failure: the C-CURE (Cardiopoietic stem Cell therapy in heart failURE) multicenter randomized trial with lineage-specified biologics. J Am Coll Cardiol 2013, 61:2329-2338

43. Zhang Y, Liao S, Yang M, Liang X, Poon MW, Wong CY, Wang J, Zhou Z, Cheong SK, Lee CN, Tse HF, Lian Q: Improved cell survival and paracrine capacity of human embryonic stem cell-derived mesenchymal stem cells promote therapeutic potential for pulmonary arterial hypertension. Cell Transpl 2012, 21:2225-2239.

44. Lian Q, Zhang Y, Zhang J, Zhang HK, Wu X, Lam FF, Kang S, Xia JC, Lai WH, Au KW, Chow YY, Siu CW, Lee CN, Tse HF: Functional mesenchymal stem cells derived from human induced pluripotent stem cells attenuate limb ischemia in mice. Circulation 2010, 121:1113-1123.

45. Kajstura J, Urbanek K, Rota M, Bearzi C, Hosoda T, Bolli R, Anversa P, Leri A: Cardiac stem cells and myocardial disease. J Mol Cell Cardiol 2008, 45:505-513

46. Li Z, Lee A, Huang M, Chun H, Chung J, Chu P, Hoyt G, Yang P, Rosenberg J, Robbins RC, Wu JC: Imaging survival and function of transplanted cardiac resident stem cells. J Am Coll Cardiol 2009, 53:1229-1240.

47. Rota M, Padin-Iruegas ME, Misao Y, De Angelis A, Maestroni S, FerreiraMartins J, Fiumana E, Rastaldo R, Arcarese ML, Mitchell TS, Boni A, Bolli R, Urbanek K, Hosoda T, Anversa P, Leri A, Kajstura J: Local activation or implantation of cardiac progenitor cells rescues scarred infarcted myocardium improving cardiac function. Circ Res 2008, 103:107-116.

48. Makkar RR, Smith RR, Cheng K, Malliaras K, Thomson LE, Berman D, Czer LS, Marban L, Mendizabal A, Johnston PV, Russell SD, Schuleri KH, Lardo AC, Gerstenblith G, Marban E: Intracoronary cardiosphere-derived cells for heart regeneration after myocardial infarction (CADUCEUS): a prospective, randomised phase 1 trial. Lancet 2012, 379:895-904.

49. Bolli R, Chugh AR, D'Amario D, Loughran JH, Stoddard MF, Ikram S, Beache GM Wagner SG, Leri A, Hosoda T, Sanada F, Elmore JB, Goichberg P, Cappetta D, Solankhi NK, Fahsah I, Rokosh DG, Slaughter MS, Kajstura J, Anversa P: Cardiac stem cells in patients with ischaemic cardiomyopathy (SCIPIO): initial results of a randomised phase 1 trial. Lancet 2011, 378:1847-1857.

50. Schoenfeld M, Frishman WH, Leri A, Kajstura J, Anversa P: The existence of myocardial repair: mechanistic insights and enhancements. Cardiol Rev 2013, 21:111-120

51. Williams AR, Hatzistergos KE, Addicott B, McCall F, Carvalho D, Suncion V, Morales AR, Da Silva J, Sussman MA, Heldman AW, Hare JM: Enhanced effect of combining human cardiac stem cells and bone marrow mesenchymal stem cells to reduce infarct size and to restore cardiac function after myocardial infarction. Circulation 2013, 127:213-223.

52. He JQ, Ma Y, Lee Y, Thomson JA, Kamp TJ: Human embryonic stem cells develop into multiple types of cardiac myocytes: action potential characterization. Circ Res 2003, 93:32-39.

53. Zhang J, Wilson GF, Soerens AG, Koonce CH, Yu J, Palecek SP, Thomson JA Kamp TJ: Functional cardiomyocytes derived from human induced pluripotent stem cells. Circ Res 2009, 104:e30-e41.

54. Caspi O, Huber I, Kehat I, Habib M, Arbel G, Gepstein A, Yankelson L, Aronson D, Beyar R, Gepstein L: Transplantation of human embryonic stem cell-derived cardiomyocytes improves myocardial performance in infarcted rat hearts. J Am Coll Cardiol 2007, 50:1884-1893.

55. Cao F, Wagner RA, Wilson KD, Xie X, Fu JD, Drukker M, Lee A, Li RA, Gambhir SS, Weissman IL, Robbins RC, Wu JC: Transcriptional and functional profiling of human embryonic stem cell-derived cardiomyocytes. PloS One 2008, 3:e3474

56. Kolossov E, Bostani T, Roell W, Breitbach M, Pillekamp F, Nygren JM, Sasse P, Rubenchik O, Fries JW, Wenzel D, Geisen C, Xia Y, Lu Z, Duan Y, Kettenhofen R, Jovinge S, Bloch W, Bohlen H, Welz A, Hescheler J, Jacobsen SE, Fleischmann BK Engraftment of engineered ES cell-derived cardiomyocytes but not BM cells restores contractile function to the infarcted myocardium. J Exp Med 2006, 203:2315-2327.

57. Laflamme MA, Chen KY, Naumova AV, Muskheli V, Fugate JA, Dupras SK, Reinecke H, Xu C, Hassanipour M, Police S, O'Sullivan C, Collins L, Chen Y, Minami E, Gill EA, Ueno S, Yuan C, Gold J, Murry CE: Cardiomyocytes derived from human embryonic stem cells in pro-survival factors enhance function of infarcted rat hearts. Nat Biotechnol 2007, 25:1015-1024.

58. van Laake LW, Passier R, Monshouwer-Kloots J, Verkleij AJ, Lips DJ, Freund C, den Ouden K, Ward-van Oostwaard D, Korving J, Tertoolen LG, van Echteld CJ, Doevendans PA, Mummery CL: Human embryonic stem cell-derived cardiomyocytes survive and mature in the mouse heart and transiently improve function after myocardial infarction. Stem Cell Res 2007, 1:9-24.

59. Shiba Y, Fernandes S, Zhu WZ, Filice D, Muskheli V, Kim J, Palpant NJ, Gantz J, Moyes KW, Reinecke H, Van Biber B, Dardas T, Mignone JL, Izawa A, Hanna R, Viswanathan M, Gold JD, Kotlikoff MI, Sarvazyan N, Kay MW, Murry CE, Laflamme MA: Human ES-cell-derived cardiomyocytes electrically couple and suppress arrhythmias in injured hearts. Nature 2012, 489:322-325.

60. Fernandes S, Naumova AV, Zhu WZ, Laflamme MA, Gold J, Murry CE: Human embryonic stem cell-derived cardiomyocytes engraft but do not alter cardiac remodeling after chronic infarction in rats. J Mol Cell Cardiol 2010, 49:941-949.

61. Nussbaum J, Minami E, Laflamme MA, Virag JA, Ware CB, Masino A, Muskheli V, Pabon L, Reinecke H, Murry CE: Transplantation of 
undifferentiated murine embryonic stem cells in the heart: teratoma formation and immune response. FASEB J 2007, 21:1345-1357.

62. Liao SY, Tse HF, Chan YC, Mei-Chu Yip P, Zhang Y, Liu Y, Li RA: Overexpression of Kir2.1 channel in embryonic stem cell-derived cardiomyocytes attenuates posttransplantation proarrhythmic risk in myocardial infarction. Heart Rhythm 2013, 10:273-282.

63. Zhang YM, Hartzell C, Narlow M, Dudley SC Jr: Stem cell-derived cardiomyocytes demonstrate arrhythmic potential. Circulation 2002, 106:1294-1299.

64. Takahashi K, Tanabe K, Ohnuki M, Narita M, Ichisaka T, Tomoda K, Yamanaka S: Induction of pluripotent stem cells from adult human fibroblasts by defined factors. Cell 2007, 131:861-872.

65. Yu J, Vodyanik MA, Smuga-Otto K, Antosiewicz-Bourget J, Frane JL, Tian S, Nie J, Jonsdottir GA, Ruotti V, Stewart R, Slukvin II, Thomson JA: Induced pluripotent stem cell lines derived from human somatic cells. Science 2007, 318:1917-1920.

66. Miki K, Uenaka H, Saito A, Miyagawa S, Sakaguchi T, Higuchi T, Shimizu T, Okano T, Yamanaka S, Sawa Y: Bioengineered myocardium derived from induced pluripotent stem cells improves cardiac function and attenuates cardiac remodeling following chronic myocardial infarction in rats. Stem Cells Trans/ Med 2012, 1:430-437.

67. Kawamura M, Miyagawa S, Miki K, Saito A, Fukushima S, Higuchi T, Kawamura T, Kuratani T, Daimon T, Shimizu T, Okano T, Sawa Y: Feasibility, safety, and therapeutic efficacy of human induced pluripotent stem cell-derived cardiomyocyte sheets in a porcine ischemic cardiomyopathy model. Circulation 2012, 126:S29-S37.

68. Zhang Y, Wang D, Chen M, Yang B, Zhang F, Cao K: Intramyocardial transplantation of undifferentiated rat induced pluripotent stem cells causes tumorigenesis in the heart. PloS One 2011, 6:e19012.

69. Gutierrez-Aranda I, Ramos-Mejia V, Bueno C, Munoz-Lopez M, Real PJ, Macia A, Sanchez L, Ligero G, Garcia-Parez UL, Menendez P: Human induced pluripotent stem cells develop teratoma more efficiently and faster than human embryonic stem cells regardless the site of injection. Stem Cells 2010, 28:1568-1570.

70. Okita K, Nakagawa M, Hyenjong H, Ichisaka T, Yamanaka S: Generation of mouse induced pluripotent stem cells without viral vectors. Science 2008, 322:949-953.

71. Warren L, Manos PD, Ahfeldt T, Loh YH, Li H, Lau F, Ebina W, Mandal PK, Smith ZD, Meissner A, Daley GQ, Brack AS, Collins JJ, Cowan C, Schlaeger $T M$, Rossi DJ: Highly efficient reprogramming to pluripotency and directed differentiation of human cells with synthetic modified mRNA. Cell Stem Cell 2010, 7:618-630.

72. Reinecke $H$, Zhang $M$, Bartosek T, Murry CE: Survival, integration, and differentiation of cardiomyocyte grafts: a study in normal and injured rat hearts. Circulation 1999, 100:193-202.

73. Liang P, Lan F, Lee AS, Gong T, Sanchez-Freire V, Wang Y, Diecke S, Sallam K, Knowles JW, Wang PJ, Nguyen PK, Bers DM, Robbins RC, Wu JC: Drug screening using a library of human induced pluripotent stem cell-derived cardiomyocytes reveals disease-specific patterns of cardiotoxicity. Circulation 2013, 127:1677-1691.

74. Dick E, Rajamohan D, Ronksley J, Denning C: Evaluating the utility of cardiomyocytes from human pluripotent stem cells for drug screening. Biochem Soc Trans 2010, 38:1037-1045.

75. Hofmann M, Wollert KC, Meyer GP, Menke A, Arseniev L, Hertenstein B Ganser A, Knapp WH, Drexler H: Monitoring of bone marrow cell homing into the infarcted human myocardium. Circulation 2005, 111:2198-2202.

76. Hou D, Youssef EA, Brinton TJ, Zhang P, Rogers P, Price ET, Yeung AC, Johnstone BH, Yock PG, March KL: Radiolabeled cell distribution after intramyocardial, intracoronary, and interstitial retrograde coronary venous delivery: implications for current clinical trials. Circulation 2005, 112:1150-1156

77. Tang J, Wang J, Guo L, Kong X, Yang J, Zheng F, Zhang L, Huang Y: Mesenchymal stem cells modified with stromal cell-derived factor 1 alpha improve cardiac remodeling via paracrine activation of hepatocyte growth factor in a rat model of myocardial infarction. Mol Cells 2010, 29:9-19.

78. Enoki C, Otani H, Sato D, Okada T, Hattori R, Imamura H: Enhanced mesenchymal cell engraftment by IGF-1 improves left ventricular function in rats undergoing myocardial infarction. Int J Cardiol 2010, 138:9-18

79. Mangi AA, Noiseux N, Kong D, He H, Rezvani M, Ingwall JS, Dzau VJ: Mesenchymal stem cells modified with Akt prevent remodeling and restore performance of infarcted hearts. Nat Med 2003, 9:1195-1201.
80. Matsumoto R, Omura T, Yoshiyama M, Hayashi T, Inamoto S, Koh KR, Ohta K, Izumi Y, Nakamura Y, Akioka K, Kitaura Y, Takeuchi K, Yoshikawa J: Vascular endothelial growth factor-expressing mesenchymal stem cell transplantation for the treatment of acute myocardial infarction. Arterioscler Thromb Vasc Biol 2005, 25:1168-1173.

81. Christman KL, Vardanian AJ, Fang Q, Sievers RE, Fok HH, Lee RJ: Injectable fibrin scaffold improves cell transplant survival, reduces infarct expansion, and induces neovasculature formation in ischemic myocardium. J Am Coll Cardiol 2004, 44:654-660.

82. Karam JP, Muscari C, Montero-Menei CN: Combining adult stem cells and polymeric devices for tissue engineering in infarcted myocardium. Biomaterials 2012, 33:5683-5695.

83. Wang B, Borazjani A, Tahai M, Curry AL, Simionescu DT, Guan J, To F, Elder SH, Liao J: Fabrication of cardiac patch with decellularized porcine myocardial scaffold and bone marrow mononuclear cells. J Biomed Mater Res A 2010, 94:1100-1110.

84. Zakharova L, Mastroeni D, Mutlu N, Molina M, Goldman S, Diethrich E, Gaballa MA: Transplantation of cardiac progenitor cell sheet onto infarcted heart promotes cardiogenesis and improves function. Cardiovasc Res 2010, 87:40-49.

85. Kutschka I, Chen IY, Kofidis T, Arai T, von Degenfeld G, Sheikh AY, Hendry SL, Pearl J, Hoyt G, Sista R, Yang PC, Blau HM, Gambhir SS, Robbins RC: Collagen matrices enhance survival of transplanted cardiomyoblasts and contribute to functional improvement of ischemic rat hearts. Circulation 2006, 114: |167-|173.

86. Addis RC, Epstein JA: Induced regeneration - the progress and promise of direct reprogramming for heart repair. Nat Med 2013, 19:829-836.

\section{$10.1186 /$ scrt381}

Cite this article as: Liao and Tse: Multipotent (adult) and pluripotent stem cells for heart regeneration: what are the pros and cons?. Stem Cell Research \& Therapy 2013, 4:151 